$3 \mathrm{mgm}$. $d l$ - $\alpha$-tocopherol per 5 minims. The booklet issued by this firm contains a brief survey of the chemistry, physiological function, and general clinical applications of vitamin $\mathrm{E}$. It is pointed out that not only may vitamin $\mathrm{E}$ be effective in combating sterility in the female in cases of habitual or threatened abor. tion, but also that types of prognancy toxmia and premature separation of the placenta as well as dysmenorrhwa and vulvovaginitis may also respond favourably to administration. It may be effective in male impotence and may produce descent of ectopic testes. About three pages of the booklet are devoted to a description of work on the relationship of vitamin $\mathbf{E}$ and the anterior pituitary, carried out in the B.D.H. Laboratories by Barrie.

\section{Earthquake near Seattle}

The United States Coast and Geodetic Survey, in co-operation with Science Service and the Jesuit Seismological Association, states that an earthquake was experienced in the State of Washington, U.S.A., on November 13, 1939, at approximately 7h. $45 \mathrm{~m} .49 \mathrm{~s}$. G.C.T. Reports of the earthquake were received from the seismographic stations at Georgetown, Chicago, Fordham, Pasadena, Pittsburgh, Tucson, St. Louis, Butte, Weston, Williamstown, Sitka, College, Philadelphia and Lincoln. From these reports, the epicentre has been calculated to have been near lat. $47^{\circ} 35^{\prime} \mathrm{N}$., long. $123^{\circ} 15^{\prime} \mathrm{WV}$., which is to the west of Bremerton and south-east of Mount Olympus. No damage has been reported. It is well known that the western side of the American continent is more liable to earthquake shocks than the eastern side, though both as regards frequency and intensity the State of California appears to have suffered moro in the past than the State of Washington or any other of the neighbouring States.

\section{The Colonial Service: Appointments and Promotions}

THe following appointments and promotions in the Colonial Service have recently been announced: G. G. Cowley, agrieultural officer, Kenya; C. J. Lawkins, agricultural officer, Nyasaland; M. A. G. Hanschell, agricultural superintendent, Iritish Guiana; J. Paine, agricultural superintendent, Gold Coast; T. A. Phillips, agricultural officer, Nigeria; H. W. T. Webb, agricultural officer, Nyasaland; R. S. T. Bowden, veterinary officer, Malaya; R. A. Hamilton, assistant meteorologist, Nigeria; J.A. Reid, research student, Institute of Medical Research, Federated Malay States; D. L. Blunt, director of agriculture, Nyasaland, to be director of agriculture, Kenya; C. J. NcGregor, agricultural officer, to be senior agricultural officer, Tanganyika Territory.

\section{The Parliamentary and Scientific Committee}

THe Parliamentary Science Committeo has now been re-formed on a new basis and will henceforward be known as the Parliamentary and Scientific Com. mittee. Following a meeting on November 8, it was agreed to form an emergency committee forthwith and to invite all former officers and members of tho executive committee to serve on it. A meeting of this emergency committee was held at tho House of Commons on Wednesday, December 6. Following the resignation of Mr. S. F. Markham as chairman in view of his forthcoming service abroad, Captain L. F. Plugge, M.P., was elected to the chairmanship. Prof. B. W. Holman and Mr. Alan E. L. Chorlton, M.P., will remain as vice.chairman and deputychairman respectively, while the new secretary is Mr. Christopher Powell. It was reported at the meeting that promises of support had been received from a large number of the organizations which previously supported the Parliamentary Science Committeo.

\section{Courses in Technical Optics}

Courses in technical optics, adapted for students with an initial training in physics or mathematics, are now being given as usual at tho Imperial College of Science and Technology, South Kensington. The Technical Optics Section was founded in 1917 to meet the demands of the optical instrument industry and the Services for assistants with an optical training; and although a good many students have taken the course since that time, the present demand exceeds the supply. There aro vacancies for a fow more students who are prepared to begin work at once. The work is of a varied character, embracing many aspects of optical knowledge in its application to industry and to other sciences, and is of great national importance.

\section{Cecil Peace Prize}

A Cecil Peace Prize of $£ 100$ is offered yearly for an essay on some subject connected with the maintenance of international peace, and having some bearing on the principles or work of the League of Nations. It is open to all undergraduates, without distinction of sex or nationality, of any university or university collego in Great Britain or Northern Iroland, who have not attained tho age of twenty-five years on the last day for submitting essays. The subject for the year 1940 is "What wero the reasons for the 'failure' of the League of Nations in the years following 1930; and what steps should bo takon after the present war to strengthen international authority ?" The essay must bo sent to tho Secretary, Universities Bureau of the British Empire, $88 \mathrm{~A}$, Gower Street, London, IV.C.1, so as to arrivo on or before November 1, 1910. Further information can bo obtained from the Secretary.

\section{Institution of Electrical Engineers}

TuE meetings of the Institution of Electrical Engineers will bo resumed in London during the second half of the current session if the present conditions continue. This applies to the ordinary meetings, informal meetings, meetings of the three technical sections and of the London Students' Section. As regards activities in the provinces, the various committees will decide in the light of local conditions whether they are able to carry out programmes of meetings, visits and functions. The first ordinary meeting of the programme for the 
second half of the session will take place on January 25 , at 6 p.m., when a discussion on "Fire-Fighting Equipment for Electrical Installations", based on the E.R.A. Report on this subject, will bo introduced by Messrs. H. W. Swann, J. Hacking and R. A. McMahon.

\section{Announcements}

Sir Arthur Syith Woodwalid, lately keeper of the Iepartment of Geology, British Museum (Natural History), has been awarded the Hayden Memorial Geological Medal of the Academy of Natural Sciences, Philadelphia. This Medal, which is awarded every three years, has been given in recognition of $\mathrm{Sir}$ Arthur's notable contributions in the field of verte. brate and invertebrate palæontology. The Hayden award was founded at the Academy in 1888 as a memorial to Ferdinand Hayden, a member of the Academy's staff and director of the United States Geological Survey; former recipients of the award include Edward Drinker Copo, Thomas H. Huxley, William Berryman Scott and Andrew C. Lawson.

Srr George Starledon, professor of agricultural botany in the University Collego of Wales, Aberystwyth, and director of the Welsh Plant Breeding Station, has been presented with the Gold Medal and certificate of honorary membership of the Royal Agricultural Society of England for distinguished services to agriculture.

The Minister of Agriculture and Fisheries has appointed two additional members to the war-time Poultry Advisory Committee recently set up to givo advice on matters affecting the interests of the poultry industry under war-time conditions. They are Captain Guy Clifford, a Lancashire poultry farmer, who is vice-president of the National Poultry Council and chairman of the Lancashire Utility Poultry Society, and Prof. T. J. Dalling, professor of animal pathology in the University of Cambridge.

MR. G. ANDREw, formerly lecturer in the Geological Department of tho Fuad el Awal University, Cairo, has been appointed Government geologist in the Anglo-Egyptian Sudan.

Mr. G. O. Jones has been appointed research fellow in the Department of Glass Technology in the University of Sheffield.

For many years it has been the practice of Emmanuel College, Cambridge, to invite suitably qualified candidates to make application for a research studentship to which the College elects in July. For the time being the governing body feels it is unable to make such an award. In certain circumstances, however, it is prepared to supplement awards of other bodies to research students who are making application, even if provisional, for admission to Emmanuel College. Applications must reach the Master, Emmanuel College, not later than June 30 in any year.
According to a report from a correspondent, which is printed in The Times of December 12, the Institute of Experimental Physics of the University of Warsaw has been totally demolished. The whole installation of the Institute has been dismantled and all the instruments for scientific research have been sent into the Reich.

A Library devoted to the history of medicine has been established at the Yale University School of Medicine. Its basis will be formed by the collections of the late Dr. Harvey Cushing and of Dr. John F. Fulton, who is Stirling professor of physiology in the Yale Faculty.

ON October 17, Dr. Thomas Parren, surgeon. general of the United States Public Health Service, received the Sedgwick Medal of the American Public Health Association for distinguished service in publio health, the presentation being made by Dr. William Rosenau, a former medallist.

EPrepsy has been made a notifiablo diseaso in California since September 19.

The sixth Australasian Medical Congress (British Medical Association), which was to have been held in Perth next September, has been postponed indefinitely.

The issue of the Nederlandsch Tijdschrift Voor Geneeskunde of November 4 contains an account of the proceedings of the autumn meeting of the Dutch Society of the History of Medicine, Mathematics and Natural Science held at Leyden on October 22.

The October issue of the Bulletin de l'Office International d'Hygiene Publique contains the statistics for Palestine of the population, birth-rate, general and infant mortality, and the incidence of infectious di-sases according to religious groups from 1933 until 1937.

A CLASSIFIED index of entomological contributions to the Scottish Naturalist, from 1871 until the end of 1938, appeared in that journal from July until November 1939. It covers a large proportion of the records of Scottish insects during the period in question and has now been issued in completo form, consisting of sixty-six pages and cover. Copies, price 2s., may be had from Messrs. Oliver and Boyd, Ltd., Tweeddale Court, $14 \mathrm{High}$ Street, Edinburgh, 1.

THE variations in the number of marriages and births in Germany within recent years are shown by the following official figures: In 1932 the marriages numbered 517,000 , in 1933639,000 , and in 1934 720,000 . In 1935 there was a fall to 651,000 and in 1936 to 610,000 , followed by a rise to 620,000 in 1937 . There has also been a recent increaso in the number of births. In 1933 they numbered 971,000 , in 1934 $1,119,000$, in $19351,164,000$. in $19361,179,000$, and in $19371,275,000$. 